Acta vet. scand. 1987, 28, 55-63.

From the Department of Reproductive Physiology and Pathology, Norwegian College of

Veterinary Medicine, Oslo, and the Norwegian Red Cattle Association, Hamar, Norway.

\title{
Herd Reproductive Performance Related to Urea Concentration in Bulk Milk
}

\author{
By E. Ropstad and A. O. Refsdal
}

\begin{abstract}
E. Ropstad and A. O. Refsdal: Herd performance related to urea concentration in bulk milk. Acta Vet. Scand. 1987, 28, 55-63. - Bulk milk samples were collected from 256 dairy herds from 4 districts in Southern Norway: Gudbrandsdal $(n=35)$, Bergen $(n=15)$, Hedmark $(n=117)$ and Hardanger $(n=89)$.

A total of 6-8 samples were collected in each herd during the indoor season. Data concerning reproductive performance, milk production and nutrition were registered for a period of 15 months starting 7 months before the first milk sample was collected. The urea levels obtained during the sampling period were averaged generating a mean urea level of each herd. The mean urea levels were related to reproductive performance.

The urea levels within districts showed only minor variations during the sampling period. The mean urea level in Hardanger was significantly higher $(\mathrm{p}<0.05)$ than in the other distrikts. This district also had the lowest fertility. Significant correlations between mean urea level and fertility were observed only in Hedmark. Fertility status (FS), an integrated index, and number of inseminations per animal inseminated were significantly affected by the interaction between mean urea level and district. Herds in Hardanger with cows treated for ovarian cysts had a significantly higher mean urea level $(p=0.02)$ than herds with non-treated cows.

The results appear to support the notion that a negative relationship may exist between bulk milk urea levels and reproductive performance. The great district variations observed indicate, however, that the practical value of such measurements is limited.
\end{abstract}

dairy cows; health; milk production; nutrition; protein.

\section{Introduction}

Feeding excessive amounts of protein may be detrimental to fertility (Jordan \& Swanson 1979, Lotthammer 1979, Piatcowski et al. 1981 and Kaim et al. 1983). Excessive amounts of easily degradable protein will result in an accumulation of ammonia in the rumen, causing increased formation of urea in the liver. Thus, the protein intake and particularly the ratio of protein to energy affect the urea levels in blood and milk (Payne et al. 1970, Hewett 1974, Kaufmann
1982, Oltner et al. 1983). According to Hewett (1974) and Depke (1981), high urea levels are associated with fertility problems. In a previous experiment (Refsdal 1983), a high correlation $(r=0.77, p<0.01)$ between herd means of urea in blood and urea in bulk milk was found, indicating that analysis of bulk milk can be used to reflect the urea status of the herd. A later study (Refsdal et al. 1985) showed that analysis of urea in bulk milk seemed to be a practical way of assessing the protein/energy ratio in the 
feeds at the herd level. The aim of the present investigation was to assess the relationship between bulk milk urea levels and the herd reproductive performance.

\section{Materials and methods}

Urea was analyzed in bulk milk samples from 256 dairy herds. The herds were located in four districts in Southern Norway, two in the western part (Bergen, $\mathrm{n}=15$ and Hardanger, $n=89$ ) and two in the eastern part (Hedmark, $\mathrm{n}=117$ and Gudbrandsdal, $\mathrm{n}=35$ ). Bulk milk samples were collected once monthly during the indoor season from October to May in Hedmark and Hardanger. In Gudbrandsdal sampling started in November. In Bergen sampling was finished in April, and no samples were obtained in March. The majority of animals were inseminated during the indoor season in all districts.

The study was performed in the period from 1982 to 1985. Samples from Hardanger were collected in 1984/85 and samples from other districts in 1982/83.

The samples of bulk milk comprised both morning and afternoon milk. The analyses normally took place on the day following sample collection. If not, the samples were kept at $4^{\circ} \mathrm{C}$ and analyzed the following day. All samples were thoroughly mixed before analysis. The analyses were performed by a Technicon Auto-Analyzer according to a method described by the manufacturer.

Data concerning reproductive performance, milk production and nutrition were obtained from fertility statistics and herd recording files. In each herd the following parameters were registered for a period of 15 months, starting 7 months before the first milk samples were collected:

- Average number of days from calving to first insemination (CFI)
- Average number of days from calving to last insemination (CLI)

- Number of animals inseminated (I)

- Average number of inseminations per animal inseminated (NIA)

- Number of animals culled due to infertility (AC)

- Non-return rate 60 days post insemination (NR60)

- Return rate 0-3 days post insemination (PRO-3)

- Average yield at first insemination (YI)

- Average yield (305 days) (Y)

- Average percentage of silage in the diet (\% Si) (yearly estimate)

- Average percentage of concentrates in the diet (\% Co) (yearly estimate)

- Fertility status (FS) expressed by the formula:

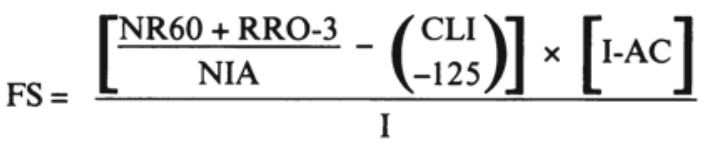

Data concerning treatments for ovarian cysts and anoestrus were obtained from 83 herds in Hardanger. These data were related to the mean urea level of October, November and December, which is the main breeding season in this district.

The urea levels obtained $(n=6-8$ samples per herd) were averaged generating a mean urea level for each herd. The mean urea levels were related to reproductive performance, milk production and nutrition. Differences among means were assessed using the Duncan's Multiple Range Test and Student's t-Test. Correlation analysis was used to assess relationship between mean urea levels and reproductive performance. The General Linear Model procedure from the Statistical Analysis System (SAS Institute Inc 1982) was used. The results were analyzed by the following model: 
$Y_{i j}=\mu+A_{i}+(A B)_{i j}+E_{i j}$,

where

$\mathrm{Y}_{\mathrm{ij}}=$ the $\mathrm{ijth}$ fertility criterion to be studied

$\mu \quad=$ general mean

$A_{i} \quad=$ effect of the ith district $(i=1 \ldots 4)$

$(A B)_{i j}=$ effect of the interaction between the ith district and the jth mean urea level $(j=2.54 \ldots 7.25)$

$\mathrm{E}_{\mathrm{ij}} \quad=$ residual random term with variance $\sigma_{\mathrm{E}}^{2}$.

\section{Results}

The overall mean urea level was $4.96 \pm$ $0.80 \mathrm{mmol} / \mathrm{l}$ ranging from $2.54-7.25 \mathrm{mmol} / \mathrm{l}$ (Fig. 1). Within districts the mean urea levels remained relatively constant during the sampling period except in herds from
Bergen, where a high urea level was observed in October (Fig. 2).

In Hardanger the mean urea level was significantly higher $(\mathrm{p}<0.05)$ than in the other districts (Table 1, Fig. 2). Herds in this district also had a higher percentage of silage and concentrates in the diet. The average yield among cows in Hardanger was lower than observed in the other districts $(\mathrm{p}<$ 0.05) (Table 1).

In Hedmark and Gudbrandsdal there was a positive correlation between urea levels and average percentage of silage in the diet $(r=$ $0.28, p=0.002$ and $r=0.50, p=0.002$, respectively) but in Hardanger a negative correlation was found $(\mathrm{r}=-0.26, \mathrm{p}=0.01)$ (Table 2).

Differences among districts existed for se-

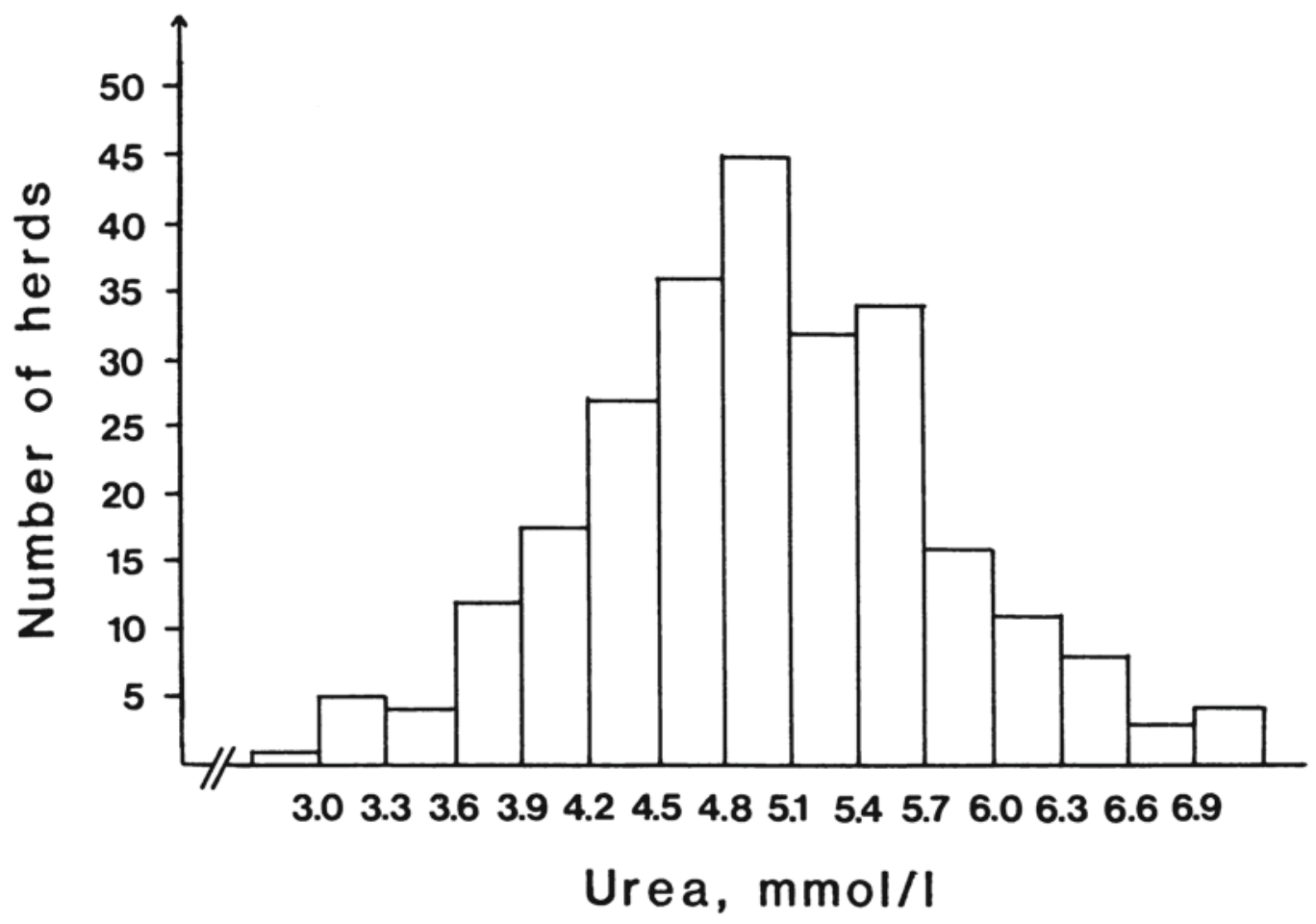

Figure 1. Frequency distribution of mean bulk milk urea levels in 256 Norwegian dairy herds sampled during the indoor season. 


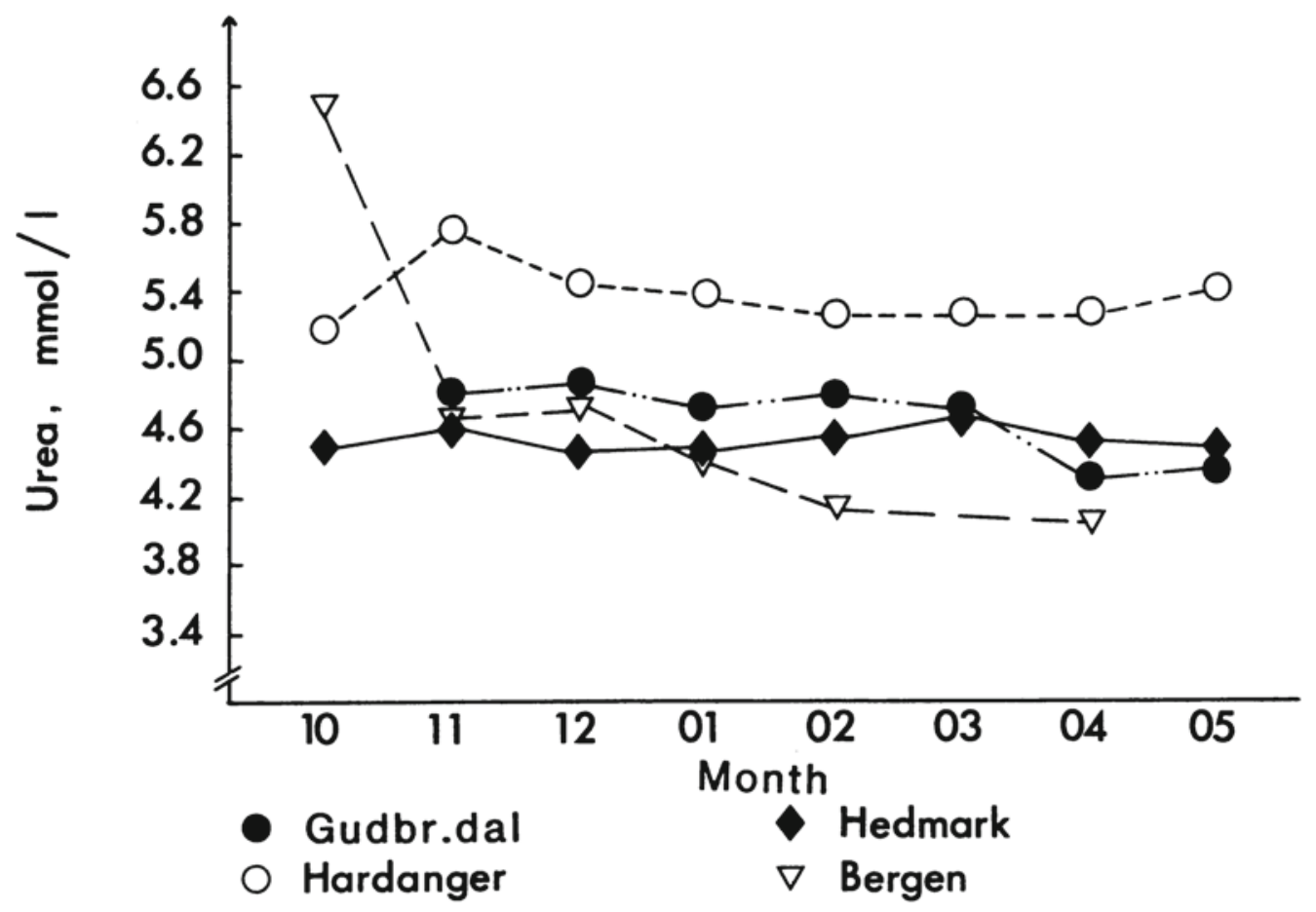

Figure 2. Mean bulk milk urea levels in 4 districts (Gudbrandsdal $n=35$, Bergen $n=15$, Hedmark $n=$ 117 and Hardanger $n=89$ ) during the indoor season.

Table 1. Differences among districts for reproductive parameters, urea level, milk yield and nutrition.

\begin{tabular}{lccccccccccc}
\hline & & \multicolumn{10}{c}{ Mean $^{1}$} \\
\cline { 3 - 11 } District & $\begin{array}{c}\text { No. of } \\
\text { herds }\end{array}$ & $\begin{array}{c}\text { Urea } \\
\text { mmol/1 }\end{array}$ & CFI & CLI & NIA & FS & NR60 & YI & Y & $\%$ Si & $\%$ Co \\
\hline Gudbrandsdal & 35 & $4.8^{\mathrm{b}}$ & $83^{\mathrm{a}}$ & $106^{\mathrm{a}}$ & $1.7^{\mathrm{a}, \mathrm{b}}$ & $58^{\mathrm{a}}$ & $61^{\mathrm{a}}$ & $24.0^{\mathrm{a}}$ & $5618^{\mathrm{a}}$ & $31^{\mathrm{b}}$ & $39^{\mathrm{b}, \mathrm{c}}$ \\
Bergen & 15 & $5.0^{\mathrm{b}}$ & $72^{\mathrm{b}}$ & $95^{\mathrm{b}}$ & $1.8^{\mathrm{a}, \mathrm{b}}$ & $64^{\mathrm{a}}$ & $54^{\mathrm{b}}$ & $24.2^{\mathrm{a}}$ & $5283^{\mathrm{a}}$ & $31^{\mathrm{b}}$ & $41^{\mathrm{b}}$ \\
Hedmark & 117 & $4.7^{\mathrm{b}}$ & $81^{\mathrm{a}}$ & $102^{\mathrm{a}}$ & $1.6^{\mathrm{b}}$ & $64^{\mathrm{a}}$ & $65^{\mathrm{a}}$ & $23.7^{\mathrm{a}}$ & $5768^{\mathrm{a}}$ & $26^{\mathrm{c}}$ & $37^{\mathrm{c}}$ \\
Hardanger & 89 & $5.4^{\mathrm{a}}$ & $76^{\mathrm{b}}$ & $90^{\mathrm{b}}$ & $1.8^{\mathrm{a}}$ & $69^{\mathrm{a}}$ & $53^{\mathrm{b}}$ & $23.3^{\mathrm{a}}$ & $5277^{\mathrm{b}}$ & $41^{\mathrm{a}}$ & $43^{\mathrm{a}}$ \\
\hline Overall mean & 256 & 5.0 & 79 & 99 & 1.7 & 65 & 60 & 23.6 & 5548 & 41 & 39 \\
\pm SD & & \pm 0.8 & \pm 11 & \pm 14 & \pm 0.3 & \pm 21 & \pm 16 & \pm 2.7 & \pm 691 & $\pm 10.0 \pm 5.9$ \\
\hline
\end{tabular}

$\mathrm{a}, \mathrm{b}, \mathrm{c}$ : Means with different superscript within columns differ significantly $(\mathrm{p}<0.05)$.

${ }^{1}:$ CFI $=$ Average number of days from calving to first insemination

CLI = Average number of days from calving to last insemination

NIA = Average number of inseminations per animal inseminated

$\mathrm{FS}=$ Fertility status $\mathrm{Y}=$ Average yield ( 305 days)

NR60 $=$ Non-return rate 60 days post partum $\% \mathrm{Si}=$ Average percentage of silage in the diet

YI = Average yield at first insemination $\% \mathrm{Co}=$ Average percentage of concentrates in the diet 
Table 2. Correlations within districts between mean urea level of the herds and reproductive parameters, milk production and nutrition.

\begin{tabular}{|c|c|c|c|c|c|c|c|c|c|c|}
\hline \multirow[b]{2}{*}{ District } & \multirow[b]{2}{*}{$\begin{array}{l}\text { No. of } \\
\text { herds }\end{array}$} & \multicolumn{9}{|c|}{ Spearman correlation coefficients, $\mathrm{r}_{\mathrm{s}}{ }^{1}$} \\
\hline & & CFI & CLI & FS & NR60 & NIA & YI & Y & \% Co & $\% \mathrm{Si}$ \\
\hline Gudbrandsdal & 35 & 0.21 & 0.02 & 0.07 & 0.08 & -0.23 & -0.13 & $0.33^{b}$ & 0.21 & $0.50^{\mathrm{c}}$ \\
\hline Bergen & 15 & 0.41 & 0.24 & -0.15 & -0.22 & -0.09 & 0.16 & 0.40 & 0.41 & 0.05 \\
\hline Hedmark & 117 & -0.13 & 0.10 & $-0.26^{\mathrm{c}}$ & $-0.19^{c}$ & $0.30^{\mathrm{c}}$ & -0.10 & $-0.17^{\mathrm{a}}$ & 0.06 & 0.28 \\
\hline Hardanger & 89 & 0.06 & 0.09 & -0.06 & -0.07 & 0.15 & $0.28^{\mathrm{c}}$ & $0.21^{\mathrm{b}}$ & $0.33^{\mathrm{c}}$ & $-0.26^{b}$ \\
\hline All & 256 & -0.06 & -0.09 & -0.10 & $-0.23^{c}$ & $0.24^{\mathrm{c}}$ & -0.03 & -0.10 & $0.39^{\mathrm{c}}$ & $0.35^{\mathrm{c}}$ \\
\hline
\end{tabular}

a, b, c: Correlation coefficients with superscripts differ significantly from zero.
a: $\mathrm{p}<0.1$
b: $p<0.05$
c: $\mathrm{p}<0.01$

1: CFI = Average number of days from calving to first insemination

CLI = Average number of days from calving to last insemination

FS $=$ Fertility status

NR60 $=$ Non-return rate 60 days post insemination

NIA = Average number of inseminations per animal inseminated

YI = Average yield at first insemination

$\mathrm{Y}=$ Average yield (305 days)

$\% \mathrm{Co}=$ Average percentage of concentrates in the diet

$\% \mathrm{Si}=$ Average percentage of silage in the diet

veral reproductive parameters (Table 1). The western districts (Hardanger and Bergen) had significantly lower non-return rates (NR60), and shorter intervals from calving to first (CFI) and last insemination (CLI) re-

spectively, than the eastern districts (Hedmark and Gudbrandsdal). Number of inseminations per pregnancy was lower in Hedmark than in the other districts $(\mathrm{p}<$ $0.05)$.

Table 3. Significance level for the effect of district and the interaction between mean urea level of the herds and district on reproductive performance in 256 dairy herds.

\begin{tabular}{|c|c|c|c|c|c|}
\hline \multirow{2}{*}{$\begin{array}{l}\text { Sources of } \\
\text { variation }\end{array}$} & \multicolumn{5}{|c|}{ Significance level, $\mathrm{p}^{1}$} \\
\hline & CFI & CLI & FS & NR60 & NIA \\
\hline District & 0.03 & 0.49 & 0.19 & 0.10 & 0.07 \\
\hline Urea $\times$ district & 0.10 & 0.41 & 0.04 & 0.12 & $<0.01$ \\
\hline $\mathrm{R}^{2}$ model & 0.11 & 0.21 & 0.07 & 0.15 & 0.12 \\
\hline
\end{tabular}

${ }^{1}:$ CFI $=$ Average number of days from calving to first insemination

$\mathrm{CLI}=$ Average number of days from calving to last insemination

FS $\quad=$ Fertility status

NR60 $=$ Non-return rate 60 days post insemination

NIA = Average number of inseminations per animal inseminated 
Table 4. Reproductive performance related to mean urea level in herds from Hedmark $(n=117)$.

\begin{tabular}{lcccccc}
\hline \multirow{2}{*}{$\begin{array}{l}\text { Mean urea } \\
\text { level } \\
\text { mmol/1 }\end{array}$} & $\begin{array}{c}\text { No. of } \\
\text { herds }\end{array}$ & CFI & CLI & NIA & NR60 & FS \\
\cline { 3 - 7 } & 30 & $81^{\mathrm{a}}$ & $99^{\mathrm{b}}$ & $1.5^{\mathrm{b}}$ & $70.0^{\mathrm{a}}$ & $73^{\mathrm{a}}$ \\
\hline 4.3 & 58 & $82^{\mathrm{a}}$ & $103^{\mathrm{ab}}$ & $1.6^{\mathrm{b}}$ & $63.3^{\mathrm{ab}}$ & $65^{\mathrm{a}}$ \\
$4.3-5.2$ & 29 & $78^{\mathrm{a}}$ & $106^{\mathrm{a}}$ & $1.8^{\mathrm{a}}$ & $60.3^{\mathrm{b}}$ & $54^{\mathrm{b}}$ \\
\hline 5.2 & 29 & & & &
\end{tabular}

a, $b$ : Means with different superscript within columns differ significantly $(\mathrm{p}<0.05)$.

${ }^{1}$ : CFI = Average number of days from calving to first insemination

CLI = Average number of days from calving to last insemination

NIA = Average number of inseminations per animal inseminated

NR60 $=$ Non-return rate 60 days post insemination

FS $\quad=$ Fertility status

Regression analysis revealed a significant effect of the interaction between mean urea level and district on fertility status $(\mathrm{p}=0.04)$ and number of inseminations per animal inseminated $(\mathrm{p}<0.01)$ (Table 3$)$. The effect of district was significant on days from calving to first insemination (CFI) $(\mathrm{P}=0.03)$.

Significant correlations between the mean urea levels of the herds and fertility were found only in Hedmark (Table 2 and 4). In this district the mean urea levels were significantly correlated with fertility status (FS) $(\mathrm{R}=-0.26, \mathrm{p}<0.01)$, non-return rate (NR60) $(\mathrm{r}=-0.19, \mathrm{p}<0.01)$ and number of inseminations per animal inseminated (NIA) $(\mathrm{r}=0.30, \mathrm{p}<0.01)$ (Table 2). Mean urea levels above $5.2 \mathrm{mmol} / \mathrm{l}$ were associated with reduced fertility in Hedmark (Table 4).
Herds in Hardanger with cows treated for ovarian cysts had higher urea means $(\mathrm{p}=$ 0.02 ) than herds with non-treated cows (Table 5).

\section{Discussion}

The fact that the study was carried out in the period from 1982 to 1985 should be taken into account when looking at differences among districts. Urea levels may change from one year to another, and the reproductive parameters registered are to some extent dependent on external factors which may change over the years. It is, however, likely that the differences observed in this study are effects of district rather than the year of sampling.

The small variation in mean urea levels seen

Table 5. Average urea levels in herds with cows treated for ovarian cysts and anoestrus compared with average urea levels in herds with non-treated cows.

\begin{tabular}{|c|c|c|c|c|c|}
\hline \multirow[b]{2}{*}{ Disease } & \multicolumn{2}{|c|}{ Herds with treated cows } & \multicolumn{2}{|c|}{ Herds with non-treated cows } & \multirow{2}{*}{$\begin{array}{l}\text { Significance level } \\
\text { for the difference between } \\
\text { the two categories, } \\
\text { p }\end{array}$} \\
\hline & $\mathrm{n}$ & $\begin{array}{l}\text { Urea, mean } \\
\mathrm{mmol} / 1\end{array}$ & $\mathrm{n}$ & $\begin{array}{c}\text { Urea, mean } \\
\mathrm{mmol} / 1\end{array}$ & \\
\hline Ovarian cysts & 21 & 5.86 & 63 & 5.40 & 0.022 \\
\hline Anoestrus & 70 & 5.85 & 14 & 5.46 & 0.110 \\
\hline
\end{tabular}


during the sampling period, is in agreement with Refsdal et al. (1985). The high October level in herds from Bergen is probably due to the fact that a majority of the animals still was on pasture at the time of sampling.

The marked difference in mean urea level between Hardanger and Hedmark is probably an effect of using different feeds. In Hardanger forage diets with grass silage as the main roughage are commonly used. According to Refsdal et al. (1985) this seems to involve a risk of feeding excessive amounts of protein and thereby elevating the milk urea levels. In Hedmark other roughages such as roots, hay, straw etc. are more commonly used in addition to grass silage.

Considering this, the negative correlation seen in Hardanger $(r=-0.26, p<0.05)$ between mean urea levels and the average percentage of silage in the diet was somewhat unexpected (Table 2). A possible explanation could be that concentrates relatively rich in protein are commonly used to replace silage in the diet in this district, thereby tending to increase urea levels. Preliminary results indicate, however, that also in Hardanger a positive correlation existed between the crude protein content of the silage dry matter and the urea levels in bulk milk, supporting Refsdal et al. (1985).

The data concerning the reproductive performance comprised both the indoor winter season and the summer season, whereas urea samples were collected during the winter season only. However, the indoor winter season is the main breeding period in all districts. Therefore the urea levels obtained should fairly well reflect the urea status of the herds at the time of breeding.

The differences seen in fertility parameters between the western and eastern districts did not influence the integrated index fertility status (FS) (Table 1). This is explained by the strong influence of the interval from calving to last insemination (CLI) on this index. In the western districts the interval from calving to last insemination was considerably shorter than in the eastern districts. This may be caused by managerial efforts taken to keep a concentrated calving period.

The lower non-return rates and higher number of inseminations per animal inseminated in the western districts may partly be due to the fact that the interval from calving to first insemination was shorter in these districts. However, according to Norwegian AI-statistics this explains only about $25 \%$ of the differences observed in non-return rates between eastern and western districts (Refsdal, unpublished data).

Hedmark was the only district in which a significant relationship between mean urea level and fertility was found (Table 2). Fertility among herds with the highest mean urea levels ( $>5.2 \mathrm{mmol} / \mathrm{l})$ was comparable with fertility in Hardanger (Table 1 and 4). In Hardanger the mean urea level was 5.4 $\mathrm{mmol} / \mathrm{l}$ and only 4 herds had urea levels below $4.3 \mathrm{mmol} / \mathrm{l}$. Therefore, if urea levels in the low range found in Hedmark have any influence on reproduction, it would be difficult to detect significant correlations in Hardanger.

A recent Norwegian study including 426 cows in 33 herds showed no relationship between the urea levels in milk from individual cows and fertility (Hårstad 1985). According to Hewett (1974) and Depke (1981) high urea levels are associated with fertility problems. The blood levels obtained by Depke averaged $6.2 \mathrm{mmol} / \mathrm{l}$, and could, according to Oltner et al. (1983), be compared with the mean urea level in milk found in Hardanger. However, also Hewett and Dep$k e$ worked with individual animals.

The high urea levels seen in herds with cows treated for ovarian cysts is probably an ex- 
pression of an undesired protein/energy ratio in the feed ration (Oltner et al. 1983, Kaufmann 1982). A negative energy balance will tend to increase the frequency of ovarian cysts and postpone the onset of ovarian activity after calving (Refsdal 1982).

The results of this study appear to support the notion that a negative relationship may exist between bulk milk urea levels and reproductive performance. Further investigations into the district variations observed are required to establish the practical value of bulk milk urea determinations.

\section{Acknowledgements}

The authors wish to thank S. R. Eriksen, K. Sørensen and L.-W. Frederiksen for excellent analytical and technical assistance. Ø. Andresen, T. Lunaas and W. Farstad are gratefully acknowledged for their valuable comments to this manuscript.

\section{References}

Depke W: Untersuchungen zur Konstitution und Fruchtbarkeit an ausgewählten Nachkommengruppen des Deutschen Schwarzbunten Milchrindes anhand von Blutserumuntersuchungen. (Studies on constitution and fertility of selected German Dairy Black Pied progeny groups as related to blood serum investigations). Diss. Tierärztliche Hochschule, Hannover 1981.

Hewett $C$ : On the causes and effects of variations in the blood profile of Swedish dairy cattle. Acta vet. scand. 1974, Suppl. 50.

Hårstad E: Sammenhengen mellom fôring, ureainnhold i mjølk og fruktbarhet hjå mjølkekyr. (The relationship between nutrition, urea content in milk and fertility in dairy cows). Thesis. Department of Animal Nutrition, The Agricultural University of Norway, 1985, 112 pp.

Jordan ER, Swanson LV: Effect of crude protein on reproductive efficiency, serum total protein and albumin in the high-producing dairy cow. J. Dairy Sci. 1979, 62, 58-63.
Kaim $M$, Folman $Y$, Neumark $H$, Kaufmann $W$ : The effect of protein intake and lactation number on post-partum body weight loss and reproductive performance of dairy cows. Anim. Prod. 1983, 37, 229-235.

Kaufmann $W$ : Variation in der Zusammensetzung des Rohstoffes Milch unter besonderer Berücksichtigung des Harnstoffgehaltes. (Variation in the urea content in milk used for processing). Milchwiss. 1982, 37, 6-9.

Lotthammer $K$ - $H$ : Einfluss der Fütterung und Futterproduktion auf Gesundheit und Fruchtbarkeit von Milchrindern. (Influence of feeding and feed production on the health and fertility of dairy cattle). Tierärztl. Prax. 1979, 7 , 425-438.

Oltner $R$, Emanuelson $M$, Wiktorsson $H$ : Factors affecting the urea concentration in cows milk. Proc., 5th Internat. Conference on Production Disease in Farm Animals, Uppsala 1983, p. 195-198.

Payne JM, Dew SM, Mantston R, Faulks M: The use of metabolic profile test in dairy herds. Vet. Rec. 1970, 87, 150-157.

Piatkowski B, Voight J, Girschewski H: Einfluss des Rohproteinniveaus auf die Fruchtbarkeit und den Harnstoffgehalt in Körperflussigkeiten bei Hochleistungskühen. (Effect of dietary crude protein content on reproduction and the urea content of body fluids in high yielding cows). Arch. Tierernähr. 1981, 31, 497-504.

Refsdal AO: Ovariecyster hos melkekyr. (Ovarian cysts in dairy cows). Norsk Vet.-T. 1982, 94, 789-795.

Refsdal $A O$ : Urea in bulk as compared to the herd mean of urea blood. Acta vet. scand. 1983, 24, 518-520.

Refsdal AO, Bavre L, Bruflot $R$ : Urea concentration in bulk milk as an indicator of the protein supply at the herd level. Acta vet. scand. 1985, 26, 153-163.

SAS Users Guide: Statistics. SAS Institute Inc. Cary N. C. 1982. 


\section{Sammendrag}

Fruktbarhetsresultater $i$ storfebesetninger relatert til ureanivåe $i$ tankmelk.

Tankmelk-prøver ble samlet fra 256 besetninger fra 4 områder i Sør-Norge: Gudbrandsdal $(n=35)$, Bergen $(n=15)$, Hedmark $(n=117)$ og Hardanger $(n=89)$. Det ble tatt ut en prøve pr. måned i hver besetning fra oktober til mai. Opplysninger om fruktbarhet, helse, melkeproduksjon og fôring ble registrert fra sju måneder før første melkêprøve ble samlet og i 15 måneder framover $\mathrm{i}$ hver besetning. Gjennomsnittsnivået for ureamålingene $\mathrm{i}$ hver besetning ble sammenholdt med fruktbarhetsresultatene.

Det var lite variasjon i ureanivåene i prøveperioden. Hardanger hadde signifikant høyere urea- nivå og dårligere fruktbarhetsresultater enn de andre distriktene. Signifikante korrelasjoner mellom ureanivå og fruktbarhet ble bare funnet $\mathrm{i}$ Hedmark. Det var en signifikant sammenheng mellom FS-tall og antall inseminasjoner pr. påbegynt ku på den ene siden og samspillet mellom ureanivå og distrikt på den andre. Besetninger $\mathrm{i}$ Hardanger hvor kyr var behandlet for cyster hadde høyere ureanivå $(\mathrm{p}=0.02)$ enn besetninger uten cystebehandlede kyr.

Undersøkelsen indikerer at høye ureanivåer i tankmelk kan være forbundet med dårlig fruktbarhet. Store distriktsvise forskjeller bidrar imidlertid til å redusere den praktiske nytten av slike målinger.

(Received November 3, 1986).

Reprints may be requested from: Erik Ropstad, Norwegian College of Veterinary Medicine, P. O. Box 8146 Dep, N-0033 Oslo 1, Norway. 